\title{
Impact of the functioning of a thermeletry in the bird fauna of the brazilian semiarid
}

The thermoelectric generate a large amount of pollutants, due to the type of fuel used for electric power generation, damaging in this way, the environment, human health, as well as the surrounding biodiversity. Based on this premise, the objective of this work was to identify the bird species present in the surroundings of a thermoelectric. The study was carried out in the surroundings of the Borborema Energética SA Thermoelectric, in the region of the northeast of Brazil, from January to December 2016, where used the technique of observation by transects and use of mist net to capture images of the bird's fauna. In the study area, 29 bird species belonging to 10 orders and 21 families were registered. The order with the most representatives was the Passeriformes, and the families were Tyrannidae, followed by Furnariidae. Of the total number of journeys performed during the daytime of the research, the species with the highest observation frequency was Crotophaga ani. On the abundance, more representatives were the species Crotophaga ani, Coragyps atratus and Thlypopsis sordida. In this context, there was a low abundance and diversity of bird's fauna in the region, demonstrating a precarious state of conservation and ecological integrity, which may reflect the impacts of industrialization, installation and operation of the thermoelectric in the area.

Keywords: Birds Fauna; Semiarid; Ambiental Degradation; Pollution; Mist Net.

\section{Impacto do funcionamento de uma termeletricidade na fauna de aves do semiárido brasileiro}

\begin{abstract}
As termoelétricas geram uma grande quantidade de poluentes, devido ao tipo de combustível utilizado na geração de energia elétrica, prejudicando, dessa forma, o meio ambiente, a saúde humana e a biodiversidade do entorno. Com base nessa premissa, o objetivo deste trabalho foi identificar as espécies de aves presentes no entorno de uma termoelétrica. O estudo foi realizado no entorno da Usina Termoelétrica Borborema Energética SA, na região nordeste do Brasil, de janeiro a dezembro de 2016, onde foi utilizada a técnica de observação por transectos e uso de rede de neblina para captura de imagens da fauna aviária. Na área de estudo, 29 espécies de aves pertencentes a 10 ordens e 21 famílias foram registradas. A ordem com o maior número de representantes era dos Passeriformes, e as famílias eram Tyrannidae, seguidas por Furnariidae. Do total de viagens realizadas durante o período diurno da pesquisa, a espécie com maior frequência de observação foi a Crotophaga ani. Na abundância, mais representantes foram as espécies Crotophaga ani, Coragyps atratus e Thlypopsis sordida. Neste contexto, houve baixa abundância e diversidade de fauna de pássaros na região, demonstrando um estado precário de conservação e integridade ecológica, o que pode refletir os impactos da industrialização, instalação e operação da termoelétrica na região.
\end{abstract}

Palavras-chave: Fauna de Aves; Semiárido; Degradação Ambiental; Poluição; Rede de Névoa.

Topic: Conservação da Biodiversidade

Reviewed anonymously in the process of blind peer.
Received: $14 / 12 / 2017$

Approved: 24/01/2018
Joaci dos Santos Cerqueira (iD)

Universidade Federal de Campina Grande, Brasil

http://lattes.cnpq.br/4470582307237189

http://orcid.org/0000-0002-0109-3849

cerq2006@gmail.com

Helder Neves de Albuquerque

Universidade Federal da Paraíba, Brasil

http://lattes.cnpq.br/1316763030688970

http://orcid.org/0000-0002-5076-3060

cerq2006@gmail.com

Francisco de Assis Salviano de Sousa (iD

Universidade Federal de Campina Grande, Brasil

http://lattes.cnpq.br/5392432872592612

http://orcid.org/0000-0002-4085-0785

cerq2006@gmail.com
Referencing this:

CERQUEIRA, J. S.; ALBUQUERQUE, H. N.; SOUSA, F. A. S.. Impact of the functioning of a thermeletry in the bird fauna of the brazilian semiarid. Revista Ibero Americana de Ciências Ambientais, v.9, n.2, p.71-83, 2018. DOI: http://doi.org/10.6008/CBPC2179-6858.2018.002.0007 


\section{INTRODUCTION}

Located in the semiarid region of the Brazilian Northeast, in the state of Paraíba, the municipality of Queimadas - PB was contemplated with the installation of a thermoelectric, which uses fossil fuels for its operation. According to Villela et al. (2007), the amount of pollutants emitted in a thermoelectric in functioning is about 1.691.287 ton/year $\mathrm{CO}_{2}$, corresponding to approximately $99 \%$ of total emissions. Therefore, with the use of this type of fuel are emitted many pollutants, which harm the environment, human health and local biodiversity. The environmental impacts generated lead to pollution, as well as air and water contamination, with increased risks to human health and biodiversity (CASTRO et al., 2013).

With regard to faunal biodiversity, South America has the richest bird fauna on the planet, with more than 2.920 species, including residents and migratory species. In Brazil, more than 1.822 bird species have been registered by the Brazilian Ornithological Records Committee, representing about $62 \%$ of all birds in the South American continent (CBRO, 2008; SICK, 2001). In the Northeastern region (semiarid) of Brazil, there are around 695 species cataloged, distributed in 20 orders and 63 families (SICK, 2001), being 4.3\% were endemic to the Caatinga (LEAL et al., 2003). Already, in the State of Paraíba, Mariano (2014) compiled a list with 395 species.

The Caatinga has been identified as an important area of endemism for South American birds, however, the distribution, evolution and ecology of the bird fauna of Caatinga remains poorly investigated, reflecting consequently on policy and conservation actions. For ICMBio (2011), the number of birds is about 510 species, which inhabit the biome Caatinga, being 23 species characterized as endemic and 33 are endangered.

Deforestation has a significant negative impact, reducing vegetation cover, which serves as a shelter and breeding place, mainly for birds (D'ÁNGEL-NETO et al., 1998). Other negative factors include pollution and environmental degradation, which are problems related to public health, due to their adverse effects on the ecosystems and the organisms that inhabit them, both fauna and flora and the human (OCHOA, 2014). The use of birds in the monitoring of environmental pollution by heavy metals has increased at present, since birds occupy a wide range at trophic levels in the food chain, are also widely distributed and sensitive to environmental changes (MALIK et al., 2009; HOFER et al., 2010).

Morphologically, the birds are characterized by being vertebrates, with modified limbs for flight, feathered body and a horny beak, devoid of teeth. They inhabit all the ecosystems, able to be found different species of birds, from the warmest to the coldest climate (DESCOURTILZ, 1983). They are a class that produce sounds, mainly by syrinx and have very similar human hearing limits, often between $20 \mathrm{~Hz}$ and $20.000 \mathrm{~Hz}$, can even produce very serious sounds in the frequency range of $80 \mathrm{~Hz}$ and also very keen sounds, in the range of $12.000 \mathrm{~Hz}$, reaching its ultrasound up to $18.000 \mathrm{~Hz}$ (SICK, 2001). The frequency range of birds' vocalization is intrinsic to the environment in which they live (KRAUSE, 1993; DIAS, 2009).

Therefore, the loss and fragmentation of habitats are the main threats to the survival of Brazilian birds, besides to excessive capture, invasion of exotic species, pollution, anthropic disturbance, natural 
disasters. With this, many species of birds are threatened with extinction. In this sense, the distribution of bird species endangered and endemic of a given biome may represent a pattern similar to that of all other endangered species (MARINI et al., 2005).

In Brazil, the trade in wild birds is nowadays recognized as an illegal activity and harmful to the environment, mainly because of the high ecological importance of these animals (BARBOSA et al., 2010). In the Brazilian semiarid region, the capture and trafficking of wild birds is widespread and, coupled with other threats, has contributed to the decline of local birds. Possibly, the persistence of hunting activities is certainly intertwined with the cultural and socioeconomic context (ALVES et al., 2010).

According to Garcia and Marini (2006) the species of birds, Herpsiloch mussellowi (chorozinho-dacaatinga), Megaxenops parnaguae (caico-billed peccary) and Picumnus limae (caatinga dwarf woodpecker) are in a list of endangered and almost endangered species in Brazil. The bird fauna is one of the most animal groups studied in Brazil, being bioreacting species. Knowledge of their ecological requirement, such as diet, foraging behavior or population dynamics, indicates environmental conditions to which they are sensitive (SABINO et al., 2011). Based on this premise, the objective of this work was to identify the bird species present in the Borborema S.A. Thermoelectric.

\section{MATERIAL AND METHODS}

The methodological procedures are based on the works of Aleixo et al. (1995); Matarazzo-Neuberger (1995); D'angelo Neto et al. (1998); Alves (2000); Antas et al. (1998); Neves et al. (1999), Hofling et al. (2002) and Telino-Júnior et al. (2005). The study was carried out around the Borborema Energética S.A Thermoelectric (UTE), within a radius of 1.000 meters. The UTE is located in the municipality of Queimadas $\mathrm{PB}$, bordering the municipality of Campina Grande - PB, transition between humid tropical climate and semiarid climate, has intermediate vegetation between the caatinga and forest, formed by xerophilous, cactaceous, deciduous and accififed, and can be divided into hyperxerophilic species of the two formations (FRANCISCO et al., 2010; IBGE, 2012; RIBEIRO et al., 2005).

By the classification of Köppen the climate is type As' (hot and humid) with average annual temperatures between 22 to $26{ }^{\circ} \mathrm{C}$. The average annual rainfall is $700 \mathrm{~mm}$, with rainfall from April to September. The relative humidity of the air is between 60 and 80\% (EMBRAPA, 1972; FRANCISCO et al., 2010; SOUZA et al., 2006). The observations were developed through the use of transects (with $10 \mathrm{~m}$ displacement free on both sides) with observation points of $10 \mathrm{~m}$ radius and, covered by three simultaneous researchers/observers, a route of $2000 \mathrm{~m}$ per route (Figure 1 ), being the total area of the bird fauna studied of 454.8 hectares.

The observations were made mainly in the morning time, once a week, with the beginning of the course between 6 and 10am and once a month during the night between 18 and 22pm to register the nocturnal birds. The direction of the course to be followed for the first observation was chosen randomly by lot to avoid bias. The other routes followed the anticlockwise direction, sequentially, during the 12 months of the research. During the execution of the course, the speed traveled was the same, with stops of 10 
minutes at the points of observation along the transect so that the observational scan avoided duplication in the visualization and counting of each specimen, being careful not to identify the same bird twice. The short stopping time at the observation points can be justified by the fact that the vegetation is sparse, which facilitates the observations, in addition, a longer time increases the risks of double registration of the same specimen.

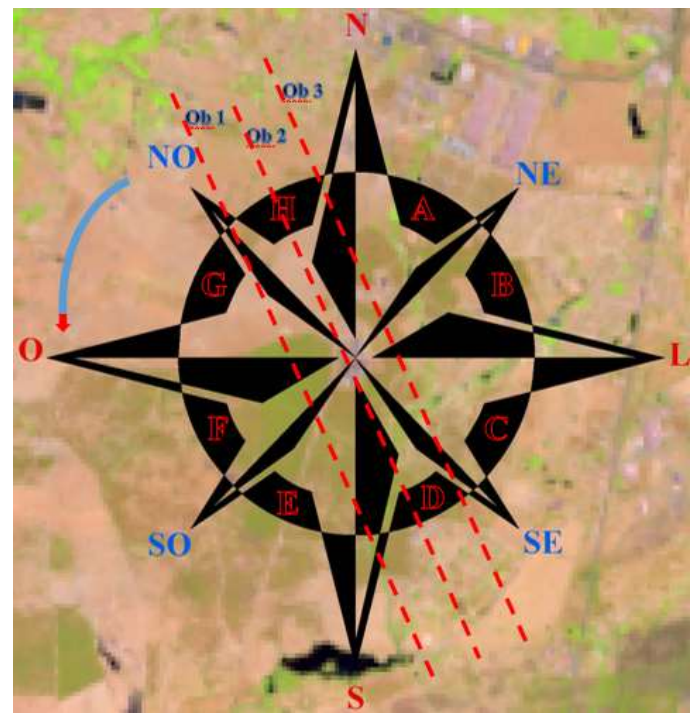

Figure 1: Model of route traveled by observers.

The research was conducted from January to December 2016, totaling 48 days and an accumulated sample effort of 192 hours (Table 1), always with the participation of 3 observers. On days when there were very strong winds and rains, no observations were made in the field, in view of the bad weather, significantly affecting the detection of birds (O'CONNOR et al., 1980; ROBBINS, 1981; SHIELDS, 1977).

In the night collections, mist nets were used, which were arranged at the beginning of the night time and collected at dawn, being monitored hourly. This technique was used to capture images of the birds fauna around the UTE, which provide an estimate of the local fauna as well as the population density of its species. Although it is more directed to those species that occur in the lower strata of forest environments, the method of capture with mist nets can be executed by observers with little training, since the identification of captured individuals is facilitated by their manipulation (PIZO et al., 2010).

As sample unit, a line of 2 (two) nets was made in the study area. As a sampling design, a line was used with 4 (four) mist nets $(12 \times 2 \mathrm{~m})$, demarcated for a period of 1 (one) day a week, and the collection operation had 3 observers. For the execution of the bird fauna studied in the surroundings of the UTE, were used binoculars 12x25, digital camera semiprofessional Canon Powershot SX60HS 16.1MP LCD 3.0, annotation block, GPS, microcomputer and peripherals, Windows and Excel of Microsoft 2016, Erdas 2010 and ArcGis 2011 , both licensed to the Digital Cartography, Geoprocessing and Remote Sensing Laboratory (CADIGEOS) of the Postgraduate Courses of the Humanities Center of the Federal University of Campina Grande (UFCG), World Computer Network, mist net and, for identification of the individuals, the methodologies of Sick (2001) and Souza's identification guide (1999) were adopted. 
Table 1: Conference log planning.

\begin{tabular}{|c|c|c|c|c|}
\hline Journey & Date & Hour & Accumulation of hours & Observers \\
\hline 1 & $05 / 01 / 2016$ & $06: 00 h-10: 00 h$ & 04:00h & JSC, HNA, MGLC \\
\hline 2 & $12 / 01 / 2016$ & $06: 00 h-10: 00 h$ & $08: 00 \mathrm{~h}$ & JSC, HNA, MGLC \\
\hline 3 & $19 / 01 / 2016$ & $06: 00 h-10: 00 h$ & $12: 00 \mathrm{~h}$ & JSC, HNA, MGLC \\
\hline 4 & $26 / 01 / 2016$ & $18: 00 h-22: 00 h$ & $16: 00 \mathrm{~h}$ & JSC, HNA, MGLC \\
\hline 5 & $02 / 02 / 2016$ & $18: 00 h-22: 00 h$ & 20:00h & JSC, HNA, MGLC \\
\hline 6 & $09 / 02 / 2016$ & $06: 00 h-10: 00 h$ & $24: 00 h$ & JSC, HNA, MGLC \\
\hline 7 & $16 / 02 / 2016$ & $06: 00 h-10: 00 h$ & $28: 00 \mathrm{~h}$ & JSC, HNA, MGLC \\
\hline 8 & $23 / 02 / 2016$ & $06: 00 h-10: 00 h$ & $32: 00 \mathrm{~h}$ & JSC, HNA, MGLC \\
\hline 9 & $08 / 03 / 2016$ & $06: 00 h-10: 00 h$ & $36: 00 \mathrm{~h}$ & JSC, HNA, MGLC \\
\hline 10 & $15 / 03 / 2016$ & $18: 00 h-22: 00 h$ & $40: 00 h$ & JSC, HNA, MGLC \\
\hline 11 & $22 / 03 / 2016$ & $06: 00 h-10: 00 h$ & $44: 00 \mathrm{~h}$ & JSC, HNA, MGLC \\
\hline 12 & $29 / 03 / 2016$ & $06: 00 h-10: 00 h$ & $48: 00 \mathrm{~h}$ & JSC, HNA, MGLC \\
\hline 13 & $05 / 04 / 2016$ & $06: 00 h-10: 00 h$ & $52: 00 \mathrm{~h}$ & JSC, HNA, MGLC \\
\hline 14 & $12 / 04 / 2016$ & $06: 00 h-10: 00 h$ & $56: 00 \mathrm{~h}$ & JSC, HNA, MGLC \\
\hline 15 & $19 / 04 / 2016$ & $18: 00 h-22: 00 h$ & $60: 00 \mathrm{~h}$ & JSC, HNA, MGLC \\
\hline 16 & $26 / 04 / 2016$ & $06: 00 h-10: 00 h$ & $64: 00 \mathrm{~h}$ & JSC, HNA, MGLC \\
\hline 17 & $03 / 05 / 2016$ & $06: 00 h-10: 00 h$ & $68: 00 \mathrm{~h}$ & JSC, HNA, MGLC \\
\hline 18 & $10 / 05 / 2016$ & $06: 00 h-10: 00 h$ & $72: 00 h$ & JSC, HNA, MGLC \\
\hline 19 & $17 / 05 / 2016$ & $06: 00 h-10: 00 h$ & $76: 00 \mathrm{~h}$ & JSC, HNA, MGLC \\
\hline 20 & $24 / 05 / 2016$ & $18: 00 h-22: 00 h$ & $80: 00 \mathrm{~h}$ & JSC, HNA, MGLC \\
\hline 21 & $07 / 06 / 2016$ & $18: 00 h-22: 00 h$ & $84: 00 \mathrm{~h}$ & JSC, HNA, MGLC \\
\hline 22 & $14 / 06 / 2016$ & $06: 00 h-10: 00 h$ & $88: 00 \mathrm{~h}$ & JSC, HNA, MGLC \\
\hline 23 & $21 / 06 / 2016$ & $06: 00 h-10: 00 h$ & $92: 00 \mathrm{~h}$ & JSC, HNA, MGLC \\
\hline 24 & $28 / 06 / 2016$ & $06: 00 h-10: 00 h$ & $96: 00 \mathrm{~h}$ & JSC, HNA, MGLC \\
\hline 25 & $05 / 07 / 2016$ & $06: 00 h-10: 00 h$ & $100: 00 \mathrm{~h}$ & JSC, HNA, MGLC \\
\hline 26 & $12 / 07 / 2016$ & $18: 00 h-22: 00 h$ & 104:00h & JSC, HNA, MGLC \\
\hline 27 & $19 / 07 / 2016$ & $06: 00 h-10: 00 h$ & 108:00h & JSC, HNA, MGLC \\
\hline 28 & $26 / 07 / 2016$ & $06: 00 h-10: 00 h$ & $112: 00 h$ & JSC, HNA, MGLC \\
\hline 29 & $02 / 08 / 2016$ & $06: 00 h-10: 00 h$ & $116: 00 \mathrm{~h}$ & JSC, HNA, MGLC \\
\hline 30 & 09/08/2016 & $06: 00 h-10: 00 h$ & $120: 00 \mathrm{~h}$ & JSC, HNA, MGLC \\
\hline 31 & $23 / 08 / 2016$ & $18: 00 h-22: 00 h$ & $124: 00 \mathrm{~h}$ & JSC, HNA, MGLC \\
\hline 32 & $30 / 08 / 2016$ & $06: 00 h-10: 00 h$ & $128: 00 \mathrm{~h}$ & JSC, HNA, MGLC \\
\hline 33 & $06 / 09 / 2016$ & $06: 00 h-10: 00 h$ & $132: 00 \mathrm{~h}$ & JSC, HNA, MGLC \\
\hline 34 & $13 / 09 / 2016$ & $06: 00 h-10: 00 h$ & $136: 00 \mathrm{~h}$ & JSC, HNA, MGLC \\
\hline 35 & 20/09/2016 & $06: 00 h-10: 00 h$ & $140: 00 h$ & JSC, HNA, MGLC \\
\hline 36 & $27 / 09 / 2016$ & $18: 00 h-22: 00 h$ & 144:00h & JSC, HNA, MGLC \\
\hline 37 & $04 / 10 / 2016$ & $18: 00 h-22: 00 h$ & $148: 00 \mathrm{~h}$ & JSC, HNA, MGLC \\
\hline 38 & $11 / 10 / 2016$ & $06: 00 h-10: 00 h$ & $152: 00 \mathrm{~h}$ & JSC, HNA, MGLC \\
\hline 39 & $18 / 10 / 2016$ & $06: 00 h-10: 00 h$ & $156: 00 \mathrm{~h}$ & JSC, HNA, MGLC \\
\hline 40 & $25 / 10 / 2016$ & $06: 00 h-10: 00 h$ & $160: 00 h$ & JSC, HNA, MGLC \\
\hline 41 & $01 / 11 / 2016$ & $06: 00 h-10: 00 h$ & $164: 00 \mathrm{~h}$ & JSC, HNA, MGLC \\
\hline 42 & $08 / 11 / 2016$ & $18: 00 h-22: 00 h$ & $168: 00 \mathrm{~h}$ & JSC, HNA, MGLC \\
\hline 43 & $22 / 11 / 2016$ & $06: 00 h-10: 00 h$ & $172: 00 \mathrm{~h}$ & JSC, HNA, MGLC \\
\hline 44 & $29 / 11 / 2016$ & $06: 00 h-10: 00 h$ & $176: 00 \mathrm{~h}$ & JSC, HNA, MGLC \\
\hline 45 & $06 / 12 / 2016$ & $06: 00 h-10: 00 h$ & $180: 00 \mathrm{~h}$ & JSC, HNA, MGLC \\
\hline 46 & $13 / 12 / 2016$ & $06: 00 h-10: 00 h$ & $184: 00 \mathrm{~h}$ & JSC, HNA, MGLC \\
\hline 47 & $20 / 12 / 2016$ & $18: 00 h-22: 00 h$ & $188: 00 h$ & JSC, HNA, MGLC \\
\hline 48 & $27 / 12 / 2016$ & $06: 00 h-10: 00 h$ & 192:00h & JSC, HNA, MGLC \\
\hline
\end{tabular}

Note: JSC = Joaci dos Santos Cerqueira; HNA = Helder Neves de Albuquerque; MGLC = Marília Gabrielle Lira Cavalcanti.

For the execution of the bird fauna studied in the surroundings of the UTE, were used binoculars 12x25, digital camera semiprofessional Canon Powershot SX60HS 16.1MP LCD 3.0, annotation block, GPS, microcomputer and peripherals, Windows and Excel of Microsoft 2016, Erdas 2010 and ArcGis 2011 , both licensed to the Digital Cartography, Geoprocessing and Remote Sensing Laboratory (CADIGEOS) of the Postgraduate Courses of the Humanities Center of the Federal University of Campina Grande (UFCG), World Computer Network, mist net and, for identification of the individuals, the methodologies of Sick (2001) and Souza's identification guide (1999) were adopted. 
Also, in the present study the following procedures and data were taken into account: information on the biology of the species; Food habit; Temporal occurrence; Social pattern, occupation of the vertical strata of space; Frequency of occurrence and abundance of each species, which were recorded according to Chart 1, below:

Chart 1: Data and descriptions for records and collection of birds.

\begin{tabular}{|c|c|}
\hline ITEM & DESCRIPTION \\
\hline Food habit & Food category for each species, defined according to the food most frequently consumed. \\
\hline Social pattern & $\begin{array}{l}\text { Classification of birds in solitary (S), par (P), homogeneous group (Gho) and heterogeneous group (Ghe) up } \\
\text { to ten individuals, homogeneous flock (Bho) and heterogeneous flock (Bhe) with more than ten individuals. }\end{array}$ \\
\hline Occupied strata & $\begin{array}{l}\text { Epigeus (ep) (on the naked, lawn or paved ground), herbaceous (herb) (up to } 0.5 \mathrm{~m} \text { in height), shrub (shr) } \\
(0.5 \mathrm{~m} \text { to } 2 \mathrm{~m} \text { in height), arboreal I (arb I) (from } 2 \mathrm{~m} \text { to } 10 \mathrm{~m} \text { high) arboreal II (arb II) (more than } 10 \mathrm{~m} \text { high) and } \\
\text { aerial (aerial) (above vegetation). }\end{array}$ \\
\hline $\begin{array}{l}\text { Frequency of } \\
\text { occurrence (FO) }\end{array}$ & $\begin{array}{l}\text { Number of days in which the species was observed in relation to the total number of days of observation: } \\
\qquad \mathbf{F O}=\frac{\mathbf{N o x} \mathbf{1 0 0}}{\mathbf{N t}} \text { s observed } \\
\text { Being - No = number of days in } \mathbf{w} \mid \\
\mathbf{N t}=\text { total number of days of observation. }\end{array}$ \\
\hline Abundance (Ab) & $\begin{array}{l}\text { Total number of individuals, of each species, recorded per hour of observation: } \\
\qquad \mathbf{A b}=\frac{\mathbf{n} \times \mathbf{1 0 0}}{\mathrm{Ho}} \\
\text { Being }-\mathbf{n}=\text { number of individual of each species } \\
\mathbf{H o}=\text { number of hours of observation. }\end{array}$ \\
\hline
\end{tabular}

Instead of simply recording the presence of the species during the observation, the data referring to the abundance estimation at each observation were also recorded, as Table 2:

Table 2: Guide to recording abundance of bird fauna.

\begin{tabular}{ll}
\hline No of individuals observed on the journey & Notation \\
\hline 1 & $\mathrm{a}$ \\
2 & $\mathrm{~b}$ \\
2 (couple) & $\mathrm{c}$ \\
3 to 5 & $\mathrm{~d}$ \\
6 to 10 & $\mathrm{e}$ \\
11 to 20 & $\mathrm{f}$ \\
21 more & $\mathrm{g}$ \\
Not determined & $\mathrm{x}$ \\
Just in overflight & $\mathrm{z}$ \\
\hline
\end{tabular}

As for the analysis, interpretation and representation of the data, simple codification and tabulation were used, presented through graphical representations with analysis and interpretation to present the data.

\section{RESULTS AND DISCUSSION}

In the surroundings of the UTE, 29 bird species belonging to 10 orders and 21 families were registered based on the list of the Brazilian Ornithological Records Committee (2006). The order with most representatives was the Passeriformes $(n=17)$ and the families were Tyrannidae $(n=5)$, followed by Furnariidae $(n=3)$, as Table 3 .

As for the representativeness of families, this study is similar to the composition of bird fauna by Araújo et al., (2006), in a study on bird diversity in Paraíba estuaries that recorded over a period of 12 months, 101 species of birds distributed in 38 families with 77 species registered in the estuary of the river Mamanguape (ERM) and 89 in the estuary of the river Paraíba (ERP), being the families that presented the 
largest number of species: Tyrannidae (13 species), Ardeidae and Scolopacidae (8 each), Columbidae (6) and Thraupidae (5). The two estuaries were very similar, regarding the specific composition of the recorded bird fauna.

Table 3: Birds observed in the surroundings of the UTE Energética Borborema S.A, classification by common name, species, order and family, 2016.

\begin{tabular}{|c|c|c|c|}
\hline Common name & Species & Order & Family \\
\hline Camo-buzzing & Anthuslutescens & Passeriformes & Motacillidae \\
\hline White heron & Ardea alba & Ciconiiformes & Ardeidae \\
\hline Giggle & Camptostomaobsoletum & Passeriformes & Tyrannidae \\
\hline Carcará & Caracaraplancos & Falconiformes & Falconidae \\
\hline Caterpillar & Coccyzusmelacoryphus & Cuculiformes & Cuculidae \\
\hline Sibitis & Coerebaflaveola & Passeriformes & Coerebidae \\
\hline Red roller & Columbina talpacoti & Columbiformes & Columbidae \\
\hline Vulture & Coragypsatratus & Cathartiformes & Cathartidae \\
\hline Gray-Headed Jackdaw & Cranioleucasemicinerea & Passeriformes & Furnariidae \\
\hline Black anu & Crotophagaani & Cuculiformes & Crotophagidae \\
\hline Blue & Cyanoloxiabrissonii & Passeriformes & Fringillidae \\
\hline Yellow-bellied Guaracava & Elaeniaflavogaster & Passeriformes & Tyrannidae \\
\hline Sealing nozzle & Estrildaastrild & Passeriformes & Estrildidae \\
\hline Hummingbird & Eupetomenamacroura & Apodiformes & Trochilidae \\
\hline Lavandeira & Fluvicolanengeta & Passeriformes & Tyrannidae \\
\hline White Anu & Guiraguira & Cuculiformes & Crotophagidae \\
\hline Bacurau & Nyctidromusalbicollis & Caprimulgiformes & Caprimulgidae \\
\hline Field Rooster & Paroaria dominicana & Passeriformes & Fringillidae \\
\hline Sparrow & Passerdomesticus & Passeriformes & Passeridae \\
\hline John twig & Phacellodomusrufifrons & Passeriformes & Furnariidae \\
\hline Bem-te-vi & Pitangussulphuratus & Passeriformes & Tyrannidae \\
\hline Swallow & Prognechalybea & Passeriformes & Hirudinidae \\
\hline Leather Jacket & Pseudoseisuracristata & Passeriformes & Furnariidae \\
\hline Burrowing owl & Speotytocunicularia & Strigiformes & Strigidae \\
\hline Canarian leave & Thlypopsissordida & Passeriformes & Thraupidae \\
\hline Nightingale & Troglodytesmusculus & Passeriformes & Troglodytidae \\
\hline Siriri & Tyrannusmelancholicus & Passeriformes & Tyrannidae \\
\hline Rip Shroud & TytoFurcata & Strigiformes & Tytonidae \\
\hline Tetouan & Vanelluschilensis & Charadriiformes & Charadriidae \\
\hline
\end{tabular}

Our data are similar to those of Sousa et al. (2011), who recorded the bird fauna of the Campina Grande - PB airport, near the UTE Borborema, registering 28 species of birds, belonging to 12 orders and 21 families, with emphasis on the most representative families Ardeidae $(\mathrm{N}=3)$ and Falconidae $(\mathrm{N}=3)$. However, it differed from the study by Menezes et al. (2004), at Campus I of the UEPB in Campina Grande, where 64 species were recorded. This difference in the abundance of bird species in Campina Grande reinforces the precarious state of conservation of the surroundings of the studied city, as well as the impact that the industries and the thermoelectric on the local bird fauna.

In another study, in the region of the western Seridó, in Rio Grande do Norte, near the State of Paraíba, whose predominant vegetation is of the Caatinga type, which presents a high state of environmental degradation, Bezerra et al. (2013) observed that of the 52 families recorded, Tyrannidae was the most representative, with 23 species. The study was conducted in 48 days, from January to December 2016, from 6 to $10 \mathrm{am}$ and from 18 to $22 \mathrm{pm}$, accumulating a total of 192 observation hours (Chart 2).

Of the total number of journals conducted during the study period, the species with the highest Frequency of Observation ( $F O$ ) were Crotophagaani ( $F O=54.17$ ); Caracara plancos ( $F O=27.08)$; Guiraguira $(F O=27.08)$ and Thlypopsis sordida $(F O=27.08)$, and lower FO was recorded for the species Cranioleuca 
semicinerea $(F O=2.08)$. In this way, the $F O$ was significant among the species $(F=10.71, g l=1, p<0.05)$, the critical F value was 4.0195 , the variance was $>104$ for FO, and $>22$ for number of observations over the period (Figure 2). During the nocturnal days, the species Nyctidromus albicollis $(\mathrm{FO}=27.08$ ) and Tyto furcata were recorded, both with $(\mathrm{FO}=4.17)$.

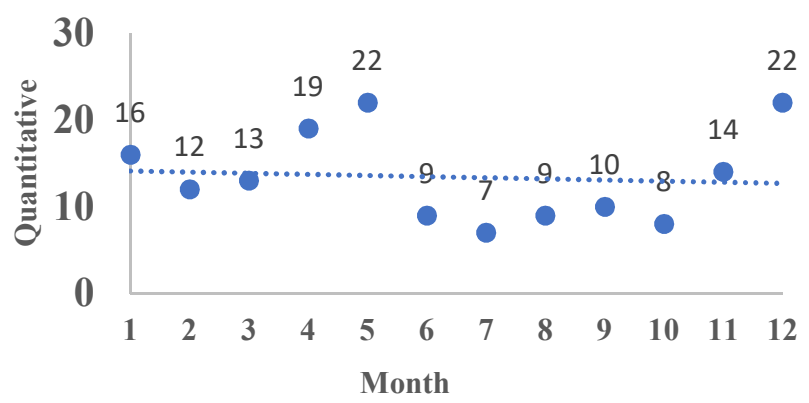

F Value $=10.71075 ; \mathrm{P}$ Value $=0.001861 ; \mathrm{F}$ Critical $=4.019541$

Figure 2: Frequency of occurrence with monthly distribution, from January to December, 2016.

In the Aluízio Campos Complex, in the city of Campina Grande - PB, close to our study site, Ferreira (2011) verified that the species of Passer domesticus and Pseudoseisura cristata were those that obtained $100 \%$ frequency of occurrence, possibly due to species that were introduced in Brazil and which adapted very well, taking advantage of the diverse wild species. Segundo (2014) in a study with birds, in Caiçara dos Quirinos farm, in Cariri Paraibano, observed that the frequency of occurrence of the bird species observed in the study area, presented a greater representativity of extremely rare species, besides a lower representativity of rare species, represented with indexes above $30 \%$, data that differ from our study.

Regarding the record of the FO of the birds observed in the vicinity of the UTE, the months that had the highest bird registration were also the months that had the highest precipitation in the area. It was also highlighted in the areas of shrub and shrub vegetation, which are located in the southeast and south, with emphasis on the southwest and west areas of the map, where vegetation is more evident, including a large number of species of fruit plants such as Spondias tuberosa (Umbu), Spondias mombin (cajá), Talisia esculenta (pitomba), Psidium cattleianum (araçá) and Ziziphus joazeiro (juazeiro).

On the food habit, Table 4, the species with the highest number of representatives were the insectivorous $(n=11)$, and the ones with the least representatives were the necrophagous $(n=1)$ and the nectarivores $(n=1)$. Regarding the occupied strata, it was identified that there was no great variation of this distribution. The social pattern, the S/P/ Gho $(n=11)$ and S/P categories, had higher scores. These data may be related to the low diversity of fauna and flora around the UTE. Thus, the prevalence of insectivorous birds is the most frequent.

In relation to the abundance of the birds, the species that presented greater abundance were: Crotophaga ani (72 individuals); Coragyps atratus (40 individuals) and Thlypopsys sordida (40 individuals), according (Figure 3). The abundance showed a significant difference between the groups $(F=5.91, g l=1, p$ $=0.001836$ ), with a variance of 62.03 , where the critical $F$ value was 4.019 and the value of $P<0.05$. 
The species Nyctidromus albicollis and Tyto furcata were only observed during the night time, with two individuals each, it is believed that the lack of food at the study site is a preponderant factor for the registration of only two individuals of the Tyto furcata species. All species recorded, according to the evaluation of the conservation status of the Brazilian birds, cycle 2010-2014, as species (Less Concern - LC), two species were classified as (Not Applicable - NA), because they are exotic species, Estrilda astrild and Passer domesticus.

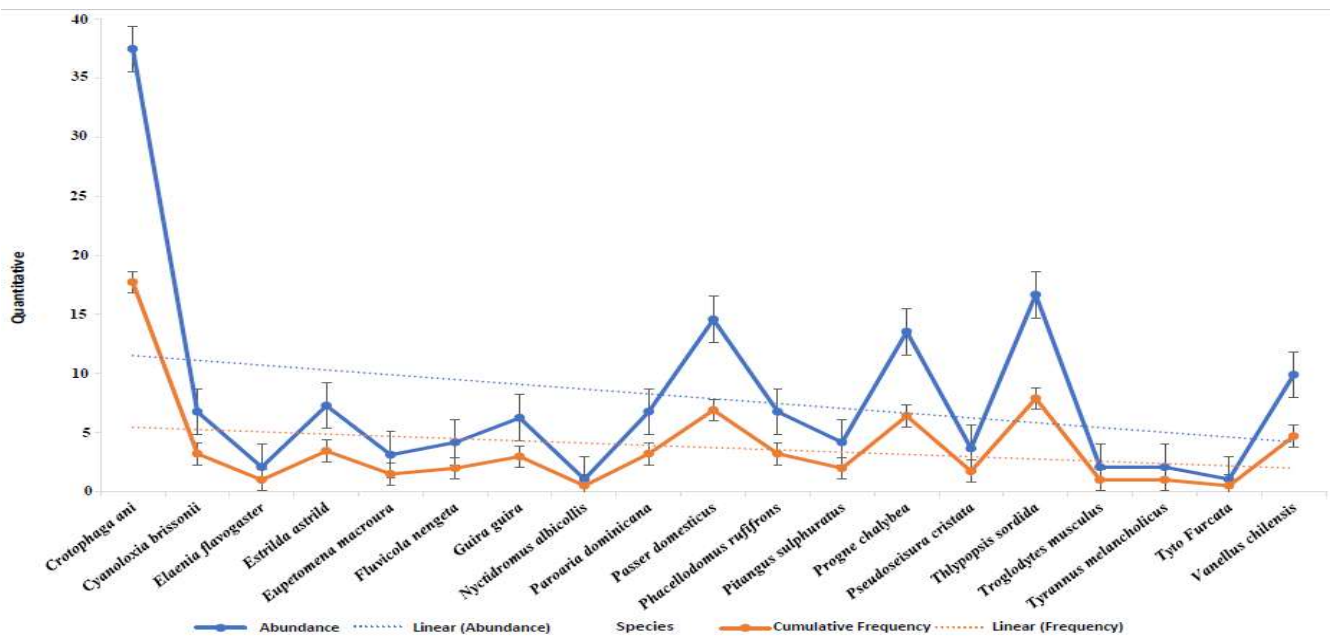

F Value $=5.914604734 ; \mathrm{P}$ Value $=0.018361963 ; \mathrm{F}$ critical $=4.01954096$

Figure 3: Variação da Abundance and Cumulative Frequency das espécies de aves identificadas no entorno da UTE, período de janeiro a dezembro de 2016.

The second largest abundance (Coragyps atratus) was due to the area being used for the disposal of cattle, horses and dead mule. Similar to our results, attention to the diversity of the family Tyrannidae, in a study realized by Mendes and Sousa (2016), in Sertão Paraibano was registered 140 species of birds, distributed in 45 families, being the three most representative families Tyrannidae (14.2\%), Thraupidae (9.2\%) and Columbidae (5.7\%). Tyrannidae species are generally insectivorous and use strategies during foraging to generate consequences of interactions of morphology, food preference, behavior, habitat selection, prey availability, and relationships between predators and competitors. Therefore, they can coexist in the same environment by sharing food resources (BISSOLI et al., 2014). Divergent to our results, in a study carried out in the Caatinga, Ceará and Pernambuco States, Olmos et al. (2005) reported that the most abundant species of birds was the Paroaria dominicana, which is believed to have occurred, because it is better adapted to low and altered Caatinga vegetation.

In addition to intensive predatory hunting and reduced native vegetation, the bird fauna have faced a big problem that affects the abundance of populations in some areas of Paraíba due to the illegal practice of domestication, which has become a cultural practice. Commonly found are caged birds in homes, bars and free fairs (DANTAS, 2015). The inspection by environmental agencies is unusual. Of particular note are Thlypopsis sordida, Cyanoloxia brissonii and Paroaria dominicana, which are constantly traded illegally at the Campina Grande/PB fairs and others. According to Silva et al. (2015), in Arapiraca/AL, a large number of wild birds are traded illegally and openly in the municipality's free market, with the most common species being the families Emberezidae and Thraupidae, and the Passeriformes and Columbiformes. 
Table 4: Species of birds observed in the surroundings of the UTE Energética Borborema S.A, classification by species, food habit, social pattern, occupied strata and abundance, 2016

\begin{tabular}{|c|c|c|c|c|c|}
\hline Species & Food habit & Social pattern & Occupied strata & $\begin{array}{l}\text { Total } \\
\text { Obs }\end{array}$ & Abundance \\
\hline Anthuslutescens & Ins & $\mathrm{S} / \mathrm{P}$ & Ep/Aer & 4 & 2,08 \\
\hline Ardea alba & Car/Ins & S/ P/ Gho & Ep & 6 & 3,12 \\
\hline Camptostomaobsoletum & Ins & $\mathrm{S}$ & Arbust/ Arb I & 4 & 2,08 \\
\hline Caracaraplancos & Oni & Gho & Arbust & 18 & 9,37 \\
\hline Coccyzusmelacoryphus & Car/Ins & $\mathrm{S} / \mathrm{P}$ & Ep & 14 & 7,29 \\
\hline Coerebaflaveola & Oni & $\mathrm{S} / \mathrm{p} / \mathrm{Gho}$ & Ep/ Aer & 5 & 2,60 \\
\hline Columbina talpacoti & Car & S/ P/ Gho & Ep/ Arbust/ Arb I/ Aer & 27 & 14,06 \\
\hline Coragypsatratus & Necro & Gho & Ep/ Arbust/ Arb I/ Aer & 40 & 20,83 \\
\hline Cranioleucasemicinerea & Ins & S/ P/ Gho & Ep/Arbust/ Arb I & 1 & 0,52 \\
\hline Crotophagaani & Ins & S/ P/ Gho & Arb I/ Aer & 72 & 37,50 \\
\hline Cyanoloxiabrissonii & Ins/ Fru & S/P/ Gho & Arb I/ Aer & 13 & 6,77 \\
\hline Elaeniaflavogaster & Ins/ Fru & S/P/ Gho & Ep/ Arbust & 4 & 2,08 \\
\hline Estrildaastrild & Gran & S/ P/ Gho/Bho & Ep/ Arbust/ Arb I/ Aer & 14 & 7,29 \\
\hline Eupetomenamacroura & $\mathrm{Nec}$ & $\mathrm{S}$ & Arbust/ Arb I/ Aer & 6 & 3,12 \\
\hline Fluvicolanengeta & Ins & $S / P$ & Ep/ Arbust/Arb I & 8 & 4,17 \\
\hline Guiraguira & Ins & S/ P/ Gho/ Bho & Ep/ Arbust/ Arb I/ Arb II/ Aer & 12 & 6,25 \\
\hline Nyctidromusalbicollis & Ins & $S / P$ & Ep & 2 & 1,04 \\
\hline Paroaria dominicana & Ins/ Fru & S/ P/ Gho & Arb I/ Aer & 13 & 6,77 \\
\hline Passerdomesticus & Oni & S/P/Gho & Ep/ Arbust/ Arb I/ Arb II/ Aer & 28 & 14,58 \\
\hline Phacellodomusrufifrons & Ins & S/P/Gho & Ep/ Arbust/ Arb I & 13 & 6,77 \\
\hline Pitangussulphuratus & Oni & $\mathrm{S} / \mathrm{P}$ & Ep/ Arbust/ Arb I/ Arb II/ Aer & 8 & 4,17 \\
\hline Prognechalybea & Ins & Gho/ Bho & Aer & 26 & 13,54 \\
\hline Pseudoseisuracristata & Car & $S / P$ & Arb II/ Aer & 7 & 3,65 \\
\hline Thlypopsissordida & Oni & S/ P/ Gho/ Bhe & Arb I/ Arb II/ Aer & 32 & 16,67 \\
\hline Troglodytesmusculus & Ins & $S / P$ & Ep/ Arbust/ Arb I & 4 & 2,08 \\
\hline Tyrannusmelancholicus & Ins & S/ P/ Gho & Arbust/ Arb I/ Arb II/ Aer & 4 & 2,08 \\
\hline TytoFurcata & Car & $\mathrm{S} / \mathrm{P}$ & Aer & 2 & 1,04 \\
\hline Vanelluschilensis & Gran & S/ P/ Gho/ Bho & Ep/ Arbust/ Arb I/ Aer & 19 & 9,90 \\
\hline
\end{tabular}

Note: Food habit. Ins = Insectivores, Fru - frugivorous, Nec - nectarivores, Necro - Necrophagous, Gran - granivorous, Car carnivorous, Oni - omnivorous. Social pattern. S - solitary, C - couple, G - group, Bh - homogeneous group, Bm - mixed group. Occupied strata. Ep - Epigeu, Herb - herbaceous, Arbust - shrub, Arb I - arboreal I, Arb II - arboreal II, Era - aerial. Abundance. Expressed in total number of individuals, of each species, recorded per hour of observation.

Another threat is the modification of the ambient noise, which can significantly alter the acoustic communication of the animals, directly interfering in the detection, discrimination and recognition of vocalization among bird species (BRUMM et al., 2005), which use the acoustic signal of vocalization to advertise potential predators and attract partners to copulate or defend territory (COLLINS, 2004; POESEL et al., 2006).

The main anthropogenic sources of noise are industries and means of transport, being considered the most important for wildlife due to its wide global distribution. These noises cause negative impacts on bird populations, which may include reduction in population density and reproductive success due to stress or masking. Bird species have ranges of auditory sensitivity related to their habits, therefore, it is not yet possible to predict the level of interference that the noise will cause on each species (LANZER, 2007).

\section{CONCLUSIONS}

The low abundance and diversity of bird species in Campina Grande demonstrate the precarious state of conservation and ecological integrity of the surrounding area of the city and may be a reflection of the impacts on the local bird fauna caused by the industrialization, the installation and operation of the Thermoelectric in the area. The majority of bird species were found in the shrub areas, after 300 meters of 
the Thermoelectric, it is believed that the noise generated by the operation of the Thermoelectric drives birds away, thus modifying their habitat that scares birds, as well as interfering directly in their behavior and reproduction. Thus, environmental degradation reduces the likelihood of success of most species.

In the areas devoid of vegetation, specimens of Caracara plancos and Coragyps atratus were observed, due to the availability of organic solid waste such as bovine, equine and domestic animals. However, frugivorous and nectarivorous birds depend on shrub beds to serve as shelter, food and reproduction, are directly affected by the disturbance of this habitat. Even so, some species of birds coexist very well with the human, is the case of the species of Tyto furcata, Passer domesticus, Columbina talpacoti, Coragyps atratus, Caracara plancos and Ardea alba due to the opportunity and availability of food. However, the other studies should be carried out in the area in order to monitor the state of environmental conservation as well as ecological integrity, better evaluating the spatial distribution and behavior of the birds in this region.

ACKNOWLEDGMENTS: This work was supported by the CNPQ (National Counsel of Technological and Scientific Development) through the doctorate scholarship and the Bioeducation Institute for the equipment and technical team.

\section{REFERENCES}

ALEIXO, A.; VIELLIARD, J. M. E.. Composição e dinâmica da avifauna da Mata de Santa Genebra, Campinas, São Paulo, Brasil. Revista Brasileira de Zoologia, Curitiba, v.12, n.3, p.493-511, 1995.

ALVES, M. A. S.. A Ornitologia no Brasil: Pesquisa Atual e Perspectivas. Rio de Janeiro: EdUERJ, 2000.

ALVES, R. R. N.; NOGUEIRA, E.; ARAUJO, H.; BROOKS, S.. Bird-keeping in the Caatinga, NE Brasil. Human Ecology, v.38, n.1, p.147-156, 2010.

ANTAS, P. T. Z.; CAVALCANTI, R. B.. Aves Comuns do Planalto Central. Brasília: UnB, 1998.

ARAUJO, H. F. P.; RODRIGUES, R. C.; NISHIDA, A. K.. Composição da avifauna em complexos estuarinos no estado da Paraíba, Brasil. Revista Brasileira de Ornitologia, v.14, n.3, p.249-259, 2006

BARBOSA, J. A. A.; NOBREGA, V. A.; ALVES, R. R. N. Aspectos da caça e comércio ilegal da avifauna silvestre por populações tradicionais do semi-árido paraibano. Revista de Biologia e Ciências da Terra, v.10, n.2, 2010.

BEZERRA, D. M. M.; ARAUJO, H. F. P.; ALVES, R. R. N.. Avifauna de uma área de Caatinga na região Seridó, Rio Grande do Norte, Brasil. Ornithologia, v.6, n.1, p.53-69, 2013.

BISSOLI, L. B.; SOUZA, M. M.; ROPER, J. J.. Espécies da família Tyrannidae partilham espaço de forrageio em um fragmento de Mata Atlântica, Brasil?. Natureza On-Line, v.12, n.5, p.235-239, 2014.
BRUMM, H.; SLABBEKOORN, H.. Acoustic communication in noise. Advances in the Study of Behavior, v.36, n.35, p.151209, 2005.

CBRO. Comitê Brasileiro de Registro Ornitológicos. Lista das Aves do brasil. 7 ed. 2008.

COLLINS, S.. Vocal fighting and flirting: the functions of birdsong. In.: MARLER, P.; SLABBEKORN, H.. Nature's Music: the Science of Birdsong. San Diego: Elsevier Academic Press, 2004. p.39-79.

DANTAS, R. R. A.. Aves da Caatinga Paraibana. Monografia (Bacharelado em Ciências Biológicas) - Universidade Federal de Campina Grande, Patos, 2015

D'ANGELO NETO, S.; VENTURIN, N.; OLIVEIRA FILHO, A. T.; COSTA, F. A. F.. Avifauna de quatro fisionomias florestais de pequeno tamanho (5-8 ha) no campus da UFLA. Revista Brasileira de Biologia, v.58, n.3, p.463-472, 1998.

DESCOURTILZ, J. T.. História Natural das Aves do Brasil: Notáveis por Sua Plumagem, Canto e Hábitos. Belo Horizonte: Itatiaia, 1983.

DIAS, A. F. S.. Comparação e Descrição de Parâmetros Acústicos do Canto de Volatinia Jacarina no Contexto de Seleção Sexual. Dissertação (Mestrado em Biologia animal) Universidade de Brasília, Brasília, 2009.

EMBRAPA. Empresa Brasileira de Pesquisa Agropecuária. Solos Do Nordeste: Levantamento Exploratório - 
Reconhecimento de Solos do Estado da Paraíba Embrapa. 1972.

FERREIRA, J. M. R;. Inventário da ornitofauna em ambientes de Caatinga no Complexo Aluízio Campos em Campina Grande-PB. Monografia (Graduação em Ciências Biológicas) - Universidade Estadual da Paraíba, Campina Grande, 2011.

FRANCISCO, P. R. M.. Classificação e mapeamento das terras para mecanização agrícola do estado da paraíba utilizando sistema de informações geográficas. Dissertação (Mestrado em Manejo de Solo e Água) - Universidade Federal da Paraíba, Areia, 2010.

GARCIA, F. I.; MARINI, M. A.. Estudo comparativo entre as listas global, nacional e estaduais de aves ameaçadas no Brasil. Natureza \& Conservação, v.4, n.2, p.24-49, out., 2006.

HOFER, C.; GALLAGHER, F. J.; HOLZAPFEL, C.. Metal accumulation and performance of nestlings of passerine bird species at an urban brownfield site. Environ pollut., v.158, n.5, p.1207-1213, 2010.

HÖFLING, E., CAMARGO, H. F. A.. Aves no Campus. São Paulo: Edusp, 2002.

IBGE. Instituto Brasileiro de Geografia e Estatística. Manual técnico da vegetação brasileira. Sistema fitogeográfico inventário das formações florestais e campestres, técnicas e manejos de coleções botânicas procedimentos para mapeamentos. Rio de Janeiro, 2012.

ICMBio. Instituto Chico Mendes. Sumário executivo do plano de ação nacional para a conservação das aves da caatinga. Ministério do Meio Ambiente, 2011.

KRAUSE, B. L.. The niche hypothesis. The Soundscape Newsletter 1993.

LANZER, M.. Efeitos do ruído de tráfego de veículos motorizados sobre aves que habitam um fragmento florestal urbano em Curitiba. Curitiba: UFPR, 2007.

MALIK, R. N.; ZEB, N.. Assessment of environmental contamination using feathers of Bubulcus ibis L., as a biomonitor of heavy metal pollution, Pakistan. Ecotoxicology, v.18, n.5, p.522-536, 2009.

MARIANO, E. F.. Relações biogeográficas entre a avifauna de floresta de altitude no Nordeste do Brasil. Tese (Doutorado em ciências biológicas zoologia) - Universidade Federal da Paraíba, João Pessoa, 2014.

MARINI, M. A.; GARCIA, F. I.. Conservação de aves no Brasil. Megadiversidade, v.1, n.1, 2005.

MATARAZZO-NEUBERGER, W. M.. Comunidades de aves de cinco parques e praças da Grande São Paulo. Estado de São Paulo, Ararajuba, n.3, p.13-19, 1995.

MENDES, D.; SOUSA, A. E. B. A.. Avifauna de uma área de Caatinga arbórea e ambientes associados no sertão paraibano, Brasil. Ornithologia, v.9, n.2, p.80-97, 2016.
MENEZES, I. R.. Aves no Campus I da Universidade Estadual da Paraíba - UEPB - em Bodocongó, Campina Grande-PB. Campina Grande: UEPB, 2004.

MENEZES, I. R.; ALBUQUERQUE, H. N.; CAVALCANTI, M. L. F. Avifauna no Campus I da UEPB em Campina Grande-PB. Revista de Biologia e Ciências da Terra, v.5, n.1, p.1-10, 2004.

NACCARI, C.; CRISTANI, M.. Common buzzards (Buteo buteo) bio-indicators of heavy metals pollution in Sicily (Italy). Environ Int. v.35, n.3, p.595-598, 2009.

NEVES, R. M. L.; TELINO-JÚNIOR, W. R.; NASCIMENTO, J. L. X.. Aves da Fazenda Tamanduá, Santa Terezinha Paraíba. Recife: Universidade Estadual de Pernambuco, 1999.

O'CONNOR, R. J.; HICKS, R. K.. The influence of weather conditions on the detection of birds during Common Bird Census fieldwork. Bird Study, Herts, n.27, p.137-151, 1980.

OCHOA, E. P.. Aves silvestres como bioindicadores de contaminación ambiental y metales pesados. CES Salud Pública, v.5, p.59-69, 2014.

OLMOS, F.; SILVA, W. A. G.; ALBANO, C. G.. Aves em oito áreas de Caatinga no sul do Ceará e oeste de Pernambuco, nordeste do Brasil: composição, riqueza e similaridade. Pap. Avuls zool. v.45, n.14, 2005.

PIZO, M. A.; GALETTI, M.. Métodos e perspectivas do estudo da frugivoria e dispersão de sementes por aves. In: ACCORDI, I.; STRAUBE, F. C.; VON MATTER, S.. Ornitologia e conservação: ciência aplicada, técnicas de pesquisa e levantamento. Rio de Janeiro: Technical Books, 2010.

POESEL, A.; FOERSTER, K.; KUNK, H. P.; JOHNSEN, A.. Early birds are sexy: male age, dawn song and extrapair paternity in blue tits, Cyanistes (formerly Parus) caeruleus. Animal Behaviour, v.72, n.3, p.531-538. 2006.

RIBEIRO, G. N; TEOTIA, H. S.. Estudo dos solos e uso atual da terra do agreste paraibano, através de sensoriamento remoto e geoprocessamento. In: SIMPÓSIO BRASILEIRO DE SENSORIAMENTO REMOTO, 12. Anais. Goiânia: INPE, 2005.

ROBBINS, C. S.. Bird activity levels related to weather. Studies in Avian Biology, Lawrence, v.6, p.301-10, 1981.

SABINO, U.; DUCA, C.. Utilização do tártaro emético no estudo de dieta de aves. Natureza on line, v.9, n.3, p.144145, 2011.

SEGUNDO, R. J. S.. Levantamento da comunidade de aves associada à vegetação de caatinga na fazenda Caiçara dos Quirinos, município de Congo, Cariri paraibano. Campina Grande: UEPB, 2014.

SHIELDS, W. M.. The effect of time of day on avian census results. Auk, Boston, v.94, p.380-383, 1977.

SICK, H.. Ornitologia Brasileira. Rio de Janeiro: Nova Fronteira, 2001.

SILVA, E. M.; LIMA, V. F. S.; OLIVEIRA, E. L. R.; BORGES, J. C. G.. Aves silvestres comercializadas ilegalmente em feiras livres da cidade de Arapiraca, Alagoas. Enciclopédia 
Biosfera, Centro Científico Conhecer, Goiânia, v.11, n.21, p.2045-2055, 2015

SOUSA, E. N. A.; LIMA, R. S.; ALBUQUERQUE, H. N.. Inventário preliminar da avifauna do aeroporto Presidente João Suassuna - Campina Grande-PB. Revista Brasileira de Informações Científicas, v.2, n.3, p.60-65, 2011.

SOUZA, D.. Todas as aves do Brasil: Guia de campo para identificação. 1 ed. Feira de Santana: DALL, 1999.
SOUZA, M. J. N.; OLIVEIRA, V. P. V.. Os enclaves úmidos e sub-úmidos do semi-árido do nordeste brasileiro. Mercator Revista de Geografia da UFC, v.5, n.9, 2006.

TELINO-JÚNIOR, W. R.; LYRA-NEVES, R. M.; NASCIMENTO, J. L. X.. Biologia e composição da avifauna em uma Reserva Particular de Patrimônio Natural da caatinga paraibana. Ornithologia, v.1, n.1, p.49-57, 2005. 